\title{
The Effect of Brand Personality and Brand Satisfaction on Brand Loyalty: A Conceptual Paper
}

\author{
Alireza Roustasekehravani (Corresponding author) \\ Faculty of Management (FM), Universiti Teknologi Malaysia \\ 81300 Skudai, Malaysia \\ E-mail: ralireza8@live.utm.my
}

\begin{abstract}
Abu Bakar Abdul Hamid
International Business School (IBS), Universiti Teknologi Malaysia

54100 Kuala Lumpur, Malaysia

E-mail:m-abakar@utm.my
\end{abstract}

\author{
Ali Abdul Hamid \\ Universiti Utara Malaysia (UUM) \\ 06010 Sintok, Kedah Darul Aman, Malaysia
}

Received: August 29, 2014 Accepted: December 2, 2014 Published: February 1, 2015

doi:10.5296/jmr.v7i2.6924 URL: http://dx.doi.org/10.5296/jmr.v7i2.6924

\begin{abstract}
Brand loyalty is one of the most-cited concepts in marketing literature, and both academic and practitioners have accepted the range of benefits derived from it. Today, brand loyalty plays a vital part in strategic management. It is surely true that the loyalty to the brand is amongst the most important company's fundamental tactics in order to acquire a maintainable competitive advantage. In order to get an understanding of brand loyalty, a discussion about the development of brand loyalty has been carried out in the following sections. The first section is about the different perspective of measurement of brand loyalty because of some argument in marketing literature and then second section is concerning potential antecedent of brand loyalty. This paper suggests a conceptual model to more understand the role of brand personality and brand satisfaction in influencing attitudinal and behavioral loyalty. The model
\end{abstract}




\section{Macrothink}

Journal of Management Research

ISSN 1941-899X

2015, Vol. 7, No. 2

will highlights the variable on which the brand loyalty depends and is helpful for managers and marketers for the better understanding of their market and also help them to better serve the needs and wants of their potential customers. This article is next established into specific research hypotheses for future studies.

Keywords: Attitudinal loyalty, Behavioral loyalty, Brand satisfaction, Brand personality 


\section{Introduction}

Loyalty lies at the core of marketing knowledge. Brand loyalty is still a very ongoing research subject. Tepeci (1999) noted the importance of brand loyalty. He argued that brand loyalty would be a more profitable approach rather than other marketing activities, such as price cuts or promotional programs. The conception of loyalty stems from the literature of customer behavior (Chegini, 2010). Following to the latest development in loyalty literature, it is observed that it is a matter of concern to the companies that consumers are currently less inclined towards the loyalty as compared to the recent past (Bennett \& Rundel-Thiele, 2005; Dekimpe, Steenkamp, Mellens, \& Vanden Abeele, 1997; Kapferer, 2005). According to the statement of Schriver (1997), in the U.S., "loyalty cannot be presumed as it was 50 years ago". A decline in the perception of brand loyalty has been found with the reference to few most famous national brands. Howell (2004) and Dekimpe et al. (1997), few privately labeled brands have been widely recognized in the present market. Ballantyne, Warren, and Nobbs (2006) Moreover, due to tough competition and fast introduction of a variety of new goods and facilities in the industry attract consumers to gain familiarity with the details of the product of a wide-ranging choice of improved and customer's friendly substitutes and prospects. Hence, it is vital for providers and industrialists make sure that their products differ in terms of quality and other features as compared to their opponents, so as to produce an attraction and liking for their services and goods (Bennett and Rundel-Thiele, 2005).

The initial empirical conceptualizations of brand loyalty were appeared during 1940s and 1950s. In these initial notions, brand loyalty was developed as a uni-dimensional construct and was described and explained in behavioural terms like market share (Cunningham, 1956) or attitudinal terms like brand preference (Guest, 1944). The one dimensional nature of the construct was challenged and debated by Day (1976) who went further to offer a two-dimensional concept of the term which consisted of behaviour and attitude. The definition of brand loyalty, which seems to be the basis for the majority of present brand loyalty studies, was developed by Jacoby (1971) based on these information.

Jacoby and Chestnut (1978) argue that brand loyalty can be examined under different approaches like attitudinal approach, behavioural approach or the compound approach. Despite the well-recognized significance of measuring loyalty as a composite construct involving attitudinal and behavioural dimensions, few studies have addressed the two-dimensional types of loyalty (Kaur \& Soch, 2013). Caceres and Paparoidamis (2007) concluded that even if many authors speak about attitudinal and behavioral measurements of loyalty the majority of measurements are attitudinal. Accordingly, Kaur and Soch (2013) suggested that in the future, researchers should consider more than one dimension of loyalty when examining the loyalty relationship. Analysing the components of brand loyalty is crucial to understanding customer reactions to marketing efforts, which differ, based on customers purchase behaviour. However, most of the researchers are not only facing problems in trying to describe loyalty, but they seem to be keen in understanding the method of development of loyalty (Chinomona, 2013; Curasi \& Kennedy, 2002; Kaur \& Soch, 2013). The research made so far in the field of loyalty is not able to provide a proper vision of the concept of loyalty phenomena (Bandyopadhyay \& Martell, 2007). The ambiguous and 
contradicting opinions have been found as a result of much of the research that exists related to loyalty (Lewis \& Soureli, 2006).

Moreover, little attempts at conceptualizing loyalty and studying its antecedents are still being made (Haghkhah et al., 2013; Lam, Shankar, Erramilli, \& Murthy, 2004; Rezaei \& Amin, 2013; Roustasekehravani \& Hamid, 2014). Generally there is not a field of theory in loyalty that is undefined. It also cannot be presumed that the methods through which loyalty are assessed in a particular situation is the same as another circumstance (Rundle-Thiele \& Bennett, 2001). That is why researchers have tried to find the significant factors determining brand loyalty through various researches. Consequences, This paper proposes a model that include essential elements of brand loyalty and how they influence brand loyalty as the main achievement factors, which are brand satisfaction, and brand personality, which have an impact on the brand loyalty. The significance of this suggested model is explained as follows. First, this study will reveal the concept of brand loyalty that involves attitudinal and behavioural loyalty as well as provide more considerable knowledge for evaluating the consumers' perception of the brand. Second, the study is valuable because makes important theoretical contributions to the understanding of the association between brand satisfaction and brand personality and how this variables effect on attitudinal and behavioral brand loyalty independently it involves several limitations and these must be acknowledged.

This paper is structured into the following parts. The initial part provides the literature review. The next part, presents the proposed model and a set of research hypotheses grounded on the theories in the previous section. Lastly, is the conclusion together with the discussion on the implications of the research and future research direction.

\section{Literature Review}

\subsection{Attitudinal and Behavioral Loyalty}

Attitudinal loyalty refers to the suitable temperament towards the brand" (Bandyopadhyay \& Martell, 2007). Later on, loyalty consequently evolved to include the attitudinal measurement tools. (Foxall, Goldsmith, \& Brown, 1998; T. O. Jones \& Sasser, 1995; Mellens, Dekimpe, \& Steenkamp, 1995). It emphasizes that; feelings are responsible for attracting an individual's overall attention towards a product or services (Fournier \& Yao, 1997). The dimensions of attitudinal loyalty include factors such as the willingness to repurchase, optimistic word-of-mouth, as well as commitment (Rundle-Thiele, 2005). In contrast to behavioural loyalty, attitudinal loyalty is distinct from common purchasing (Dekimpe et al., 1997). The structure of the customer's knowledge, either mental or emotional, behaves as a mediator between stimuli and responses (Zins, 2001).

Behavioural loyalty can be seen through a promising repeat buying pattern (Bandyopadhyay \& Martell, 2007). Copeland (1923) initiated the first studies on loyalty with his research on sole brand loyalty where he had adopted a behavioral perspective. In the behaviorists' perspective, brand loyalty's intensity can be assessed by a particular brand's purchase (Brody \& Cunningham, 1968) or the chances of purchase (Farley, 1964). Loyalty has been considered as a measurement of the behaviour of customers (Liu, 2006; Loveman, 1998) by 
various researchers (Aydin \& Özer, 2005; Aydin, Özer, \& Arasil, 2005; Edvardsson, Johnson, Gustafsson, \& Strandvik, 2000). The actual behaviour of the customer is the best way to evaluate the loyalty of customers to a product, as described by the researchers. However, many researchers have questioned the capability of utilizing behaviour as a degree of loyalty. Researchers have considered behavioural loyalty as a significant dimension, "but is not an adequate antecedent of real loyalty" (Baloglu, 2002). Conversely, the mainstream of empirical studies on the dimensionality of brand loyalty tend to agree that brand loyalty is a multi-dimension construct, but their results on the structure of brand loyalty tend to be divergent. Therefore, both the behavioural and attitudinal factors have been considered in this study. Operationalizing this combined explanation of loyalty to brand still demonstrated to be extremely challenging. Nevertheless, since this is the only fully recognized definition that acknowledges the possibility of multi brand loyalty, even if it does not make the perfect measuring instrument, it did provide a sound conceptual framework for this research.

\subsection{Brand Satisfaction}

Satisfaction appears when the performance of a brand meets the anticipations of the purchaser (He, Li, \& Harris, 2012). The satisfied customers are, less sensitive to price movements, more loyal and more likely to involve in positive word of mouth behavior (Anderson, Fornell, \& Mazvancheryl, 2004; Brady \& Robertson, 2001; Matzler, Füller, Renzl, Herting, \& Späth, 2008; Rezaei, 2015) The considerable conversation has been revealed in the literature regarding to the explanation and evaluation of satisfaction (Babin \& Griffin, 1998; Bloemer, De Ruyter, \& Peeters, 1998; Giese \& Cote, 2000; M. A. Jones \& Suh, 2000). It has been the field of main interest for many of the marketing managers. It is generally referred as a standard of a company's success (Bennett \& Rundle-Thiele, 2004). In recent years, the concept of satisfaction has grasped attention based on the operation of its paradigm shift from transactional marketing to relationship marketing involving all activities in the business of maintaining successful relational exchanges (Ojo, 2010; Roustasekehravani \& Hamid, 2014). As discussed earlier, brand satisfaction in this study refer to the overall pleasure or contentment the customer associates with the brand, fulfilling needs, wishes, and expectations (Nadeem, 2007). Consequently, one of the main components of brand loyalty is the satisfaction with the preferred brand.

\subsection{Brand Personality}

Brand personality has been defined as "the set of human features related to a brand" (Aaker, 1997). Aaker (1997) has defined personality in terms of characteristics instead of the other psychologists that described it on the basis of traits. The demographic features come under the term of brand personality, such as social class, gender and age and they are affected by the image of brand users, product spokesperson and personnel and are indirectly influenced by the features of the product (Levy, 1999). Consumers tend to provide more favourable product evaluation based on the fit between self-concept and brand personality (Freling \& Forbes, 2005). As an example a brand of cigarette named Marlboro is generally perceived to be used by males as "macho cowboys" is the symbol of brand image created by a brand. Similarly, Mercedes cars are thought to be used in higher classes as it presents an image of 
superior quality and performance. The customers generally opt for those brands, which match their personalities with that shown by the people. Thus, they create a kind of association with brands as they do with human beings (Aggarwal, 2004). Brand personality in this study defied as the set of human personality traits that correspond to the interpersonal domain of human personality and those which are relevant to describing the brand as a reciprocal partner in the consumer-brand relationship Sweeney and Brandon (2006).

Customers generally prefer those brands, which have self-concept analogy (Kotler \& Keller, 2005). Plummer (2000) claimed that brand personality might be vital in understanding the choice of brand. Consumers are more inclined towards the usage of those brands and products, which matches their features of personality. Therefore, the marketing department focuses on making customers believe and recognize a brand personality, and enhancing the relation between the brand and the consumers to create an equity and brand loyalty (Govers \& Schoormans, 2005).

\section{Research Framework}

This conceptual paper suggests the two main antecedents of brand loyalty, which is derived from the theoretical foundations of prior research in marketing literature. Brand personality as well as brand satisfaction are widely used and accepted to explain the relationship between perceptions and the use of products. The two main constructs that influence behavioural intention and loyalty toward brand. Past investigators have postulated evidence of the significant effect of brand personality on brand satisfaction. Brakus, Schmitt, and Zarantonello (2009) believe brand personality to have significant direct impacts on brand satisfaction and loyalty. The existence of a connection or relationship between consumer satisfaction and brand loyalty was proposed by Yi and La (2002) and Ouwersloot and Tudorica (2001) in the past. In this regard, Louis and Lombart (2010) revealed the attributes of Coca-Cola's brand personality to have notable positive effect on the degree to which consumers are satisfied with the brand. Grounded on the literature, the following hypotheses were established:

H1: There is a positive relationship between brand personality and brand satisfaction.

In specific, the study suggests a model that tests the impact of brand personality on attitudinal and behavioral loyalty. The investigations carried out by Mengxia (2007) have shown that the impact of brand personality on customers' purchasing intention, loyalty, brand preference and affection, the results showed positive signs of these elements.. After investigation Guo (2003) also found that brand personality has substantial impact on brand preference as a number of interviewees agreed on the cognition of some brand personalities in the brands they prefer.

On a more particular note; the notable positive effects of retailer personality (or the personality characteristics) on the attitude of consumers toward the retailer has been examined by Ben Sliman, Ferrandi, Merunka, and Valette-Florence (2005) and Helgeson and Supphellen (2004). Chen (1998) found out that a more unique brand personality might result in a firmer brand loyalty. In the study conducted by Merrilees and Miller (2001) they show 
that the perceived sincerity of a retail brand affects store loyalty directly; they however do not observe and remark on brand loyalty's remaining four dimensions. By contrast, Zentes, Morschett, and Schramm-Klein (2008) and Lombart and Louis (2012) have shown that the brand personality of a retailer can be used to adequately explain the attitudinal loyalty of consumers to the retail brand, but it is not sufficient to explain behavior. L.-Y. Lin (2010) demonstrated that the positive relationship between brand personality and brand loyalty is not completely supported. Based on the above studies, we propose the following hypotheses.

$\mathrm{H} 2$ : There is a positive relationship between brand personality and attitudinal brand loyalty.

H3: There is a positive relationship between brand personality and behavioural brand loyalty.

Brand loyalty is completely differentiated and separated from brand satisfaction. In satisfaction, the degree to which the expectations of consumer are met by a particular brand is evaluated and measured whereas in loyalty, the likelihood of customer's return along with the degree of the consumer's willingness to engage in partner-like activities for the services or products are assessed and measured (Bowen \& Shoemaker, 1998). Although customer satisfaction has been identified as necessity and requirement for loyalty, it does not imply that satisfied customers will necessarily become loyal customers (Bowen \& Shoemaker, 1998). Furthermore, despite the importance of preserving satisfied customers, loyal customers hold greater importance in comparison since a satisfied customer who does not spread positive word of mouth and has no returning intention does not possess any net present value for the firm. Thus, creating satisfied customers is not sufficient by itself since it does not ensure that they will return to buy the brand (Kandampully \& Suhartanto, 2000). In general, it has been suggested that higher satisfaction is identified with higher loyalty (Ball, Coelho, \& Machás, 2004; Hallowell, 1996; Stauss \& Neuhaus, 1997). Satisfaction plays an important role in building loyalty toward brand. As a general guideline, customer satisfaction and brand loyalty are quite nearly identified (H.-H. Lin \& Wang, 2006). The significant positive influence of brand satisfaction on brand loyalty has been confirmed in several studies (Ekinci, Dawes, \& Massey, 2008; Magin, Algesheimer, Huber, \& Herrmann, 2003).

Based on the assertion of a number of researchers, loyalty has to be evaluated and measured by combining the behavioural and attitudinal dimensions. Based on these researches brand loyalty results from multi-dimensional cognitive attitudes toward a particular brand and the repeated purchasing behaviour. Thus the two concepts of attitude and behaviour were suggested to be mixed and combined within a single theoretical definition by Jacoby (1971). According to Baloglu (2002), the reason for customers' purchase of the brand cannot be explained by focusing only on behavior (for instance the repeated purchasing behavior) and the situational factors, familiarity and competitive effects (for instance shared loyalty or multi-brand) cannot be explained by examining attitude alone. Based on a great number of researches, satisfaction is an antecedent of brand intention and attitude (Bennett, 2001; Eddy, 1999; Oliva, Oliver, \& MacMillan, 1992; Patterson \& Spreng, 1997) along with attitudinal brand loyalty (Ringham, Johnson, \& Morton, 1994). Customer satisfaction has been proposed as one of the factors that encourage customers to remain with a particular brand. In cases where customers feel satisfied with their chosen brand's performance, they are expected to 
exhibit high attitudinal loyalty (M. A. Jones \& Suh, 2000). The behavioural loyalty viewpoint is in related to repeat patronage's concept. Earlier researches have established the relationship between behavioural loyalty and satisfaction (Liang \& Wang, 2004, 2007). Therefore the relationship between behavioural and attitudinal brand loyalty with satisfaction is hypothesized as followed:

H4: There is a positive relationship between brand satisfaction and attitudinal brand loyalty.

H5: There is a positive relationship between brand satisfaction and behavioral brand loyalty.

A connection between behavior and attitude has been proposed where attitude leads to behavior (Ajzen \& Fishbein, 1980; Baldinger \& Rubinson, 1996; O'brien, 1971; Sheth \& Venkatesan, 1968). But this relationship is not unconditional despite it have been proposed since behavior cannot predicted by attitude all the time (Kraus, 1995). Other variables including situational factors, norms and variety seeking can intervene (Ajzen, Timko, \& White, 1982). Through conducting a meta-analysis study of eighty eight attitude-behavior researches it has been discovered that although behavior can significantly be predicted by attitude, the relationship is obvious in just $62 \%$ of the cases (Kraus, 1995). There are various explanations for this inconsistency in different cases one of which is the effect of uncontrollable environmental factors and situational factors (Ajzen \& Fishbein, 1980). Attitude serves as a better predictor in cases where the attitude of customers is shaped by their direct experience with the attitude object rather than instances where they experience an indirect experience (Fazio \& Zanna, 1978). In contrast Bennett, Härtel, and McColl-Kennedy (2005) believe attitudes to be predictors of behavior in business sector where critical accountability and important processes of decision-making are involved. Behavioral loyalty is one of the perceivable results of attitudinal loyalty. Although positive attitude is among the significant goals, it is not essentially in agreement with behavior thus latent loyalty can occur because of the barriers that can be created between behavior and attitude as a result of situational effects. This finding has been explained through the reasoned action theory by Fishbein and Ajzen (1975) where they noted that a particular behavior is based on a specific attitude (where specific degree of involvement is assumed) and some situational influences may take place between behavior and attitude. Although there are mixed evidences in the findings of attitude-behavior researches, behavioral loyalty and attitudinal loyalty are expected to have a notable relationship. That is why a relationship between behavioral brand loyalty and attitudinal brand loyalty was hypothesized in this research as:

H6: There is a positive relationship between attitudinal brand loyalty and behavioral brand loyalty. 


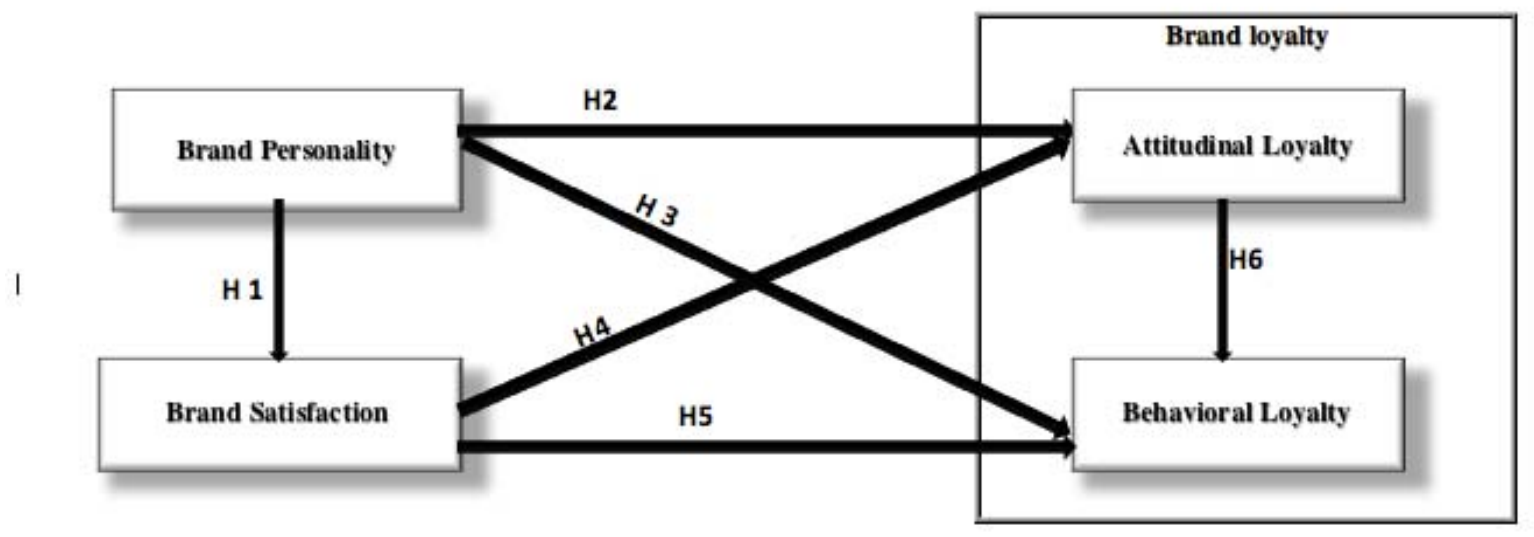

Figure 1. Research Framework

From the available literature this paper draws on the importance of integration between brand personality, brand satisfaction, attitudinal and behavioral brand loyalty, which is currently not a common practice. As discussed earlier, brand personality appears to be a key component in achieving brand loyalty. Yet, most of the researchers are not only facing problems in trying to describe loyalty, but they seem to be keen in understanding the method of development of loyalty (Chinomona, 2013; Curasi \& Kennedy, 2002; Kaur \& Soch, 2013; Roustasekehravani \& Hamid, 2014). The proposed study direction is in line with Kaur and Soch (2013) suggested that in the future, researchers should consider more than one dimension of loyalty when examining the loyalty relationship. Analyzing the components of brand loyalty is crucial to understanding customer reactions to marketing efforts, which differ, based on customers purchase behavior.

This research is significant because makes important theoretical contributions to the understanding of the association between brand personality and brand satisfaction and how this variables effect on brand loyalty independently it involves several limitations and these must be acknowledged. This study will also reveal the relationship between concept of behavioral loyalty and attitudinal loyalty. This study will empirically measure brand loyalty and its antecedents in mobile phone industry in Malaysia. The date will gather from Mobile phone user (aged 18 or over) who had favorite mobile phone in different shopping and public places of Kuala lumpur. The structural equation modeling will be used to analyze the data. Based on the above issues, the present study will designed to determine the effect of brand personality as an important antecedent to brand loyalty in very competitive mobile phone industry. The analysis is based on findings and theories from the consumer personality psychology and consumer behavior literature. These results provide important insights into the effects of brand personality in creating satisfaction and brand loyalty in order to have competitive advantage in today market.

\section{Conclusions and Future Research}

In line with the previously discussed subjects, the objective of this research is to gain an 
understanding of the relationship between brand personality and its results. On a theoretical level, the research proposes a model of the outcomes of brand personality which consists of brand satisfaction that is resulted from future behavioral intentions and attitude. Past studies tended to concentrate on particular connections. According to various researchers, attaining and keeping brand loyalty is a difficult task that requires the appropriate brand personality and satisfaction. This possess different challenges for marketing experts who are assigned with improving and enhancing the brand loyalty; however, it also offers an opportunity for researchers for further investigations to gain a better understanding of the relationships. The significance of measuring attitudinal brand loyalty and behavioral brand loyalty in gaining a better understanding and developing a better measurement of brand loyalty has been emphasized in this research. The significance of brand loyalty has been observed by Tepeci (1999). He believes brand loyalty to be a more profitable approach in comparison to other marketing activities like promotional programs or price cuts. The most significant finding of this research is that it is important for marketing managers to examine the components that lead to the loyalty of their customers and then find out the constituents of their loyalty. Without this understanding, it is hard for a company to determine the specific actions that are likely to lead to the greatest loyalty improvements. This research could also be expanded to include different types of respondents and different types of brands in the market. The current study has only examined the relationship among brand personality, brand satisfaction and attitudinal and behavioral loyalty; future research should incorporate more variables of interest based on loyalty frameworks. This study did not investigate other possible extraneous factors that could affect brand satisfaction besides brand loyalty. Further research in this field would be of great help in different types of brand and industry. As mentioned in the literature review one of the biggest challenges in marketing literature is evaluating the wide range of factors directly related to attitudinal and behavioral loyalty.

\section{References}

Aaker, Jennifer L. (1997). Dimensions of brand personality. Journal of Marketing research, 347-356. http://dx.doi.org/10.2307/3151897

Aggarwal, Pankaj. (2004). The effects of brand relationship norms on consumer attitudes and behavior. Journal of consumer research, 31(1), 87-101. http://dx.doi.org/10.1086/383426

Ajzen, Icek, \& Fishbein, Martin. (1980). Understanding attitudes and predicting social behaviour.

Ajzen, Icek, Timko, Christine, \& White, John B. (1982). Self-monitoring and the attitude-behavior relation. Journal of personality and social psychology, 42(3), 426. http://dx.doi.org/10.1037/0022-3514.42.3.426

Anderson, Eugene W, Fornell, Claes, \& Mazvancheryl, Sanal K. (2004). Customer satisfaction and shareholder value. Journal of Marketing, 172-185. http://dx.doi.org/10.1509/jmkg.68.4.172.42723

Aydin, Serkan, \& Özer, Gökhan. (2005). The analysis of antecedents of customer loyalty in the Turkish mobile telecommunication market. European Journal of Marketing, 39(7/8), 
910-925. http://dx.doi.org/10.1108/03090560510601833

Aydin, Serkan, Özer, Gökhan, \& Arasil, Ömer. (2005). Customer loyalty and the effect of switching costs as a moderator variable: A case in the Turkish mobile phone market. Marketing intelligence $\quad \& \quad$ planning, 23(1), 89-103. http://dx.doi.org/10.1108/02634500510577492

Babin, Barry J, \& Griffin, Mitch. (1998). The nature of satisfaction: an updated examination and analysis. Journal of Business Research, 41(2), 127-136. http://dx.doi.org/10.1016/S0148-2963(97)00001-5

Baldinger, Allan L, \& Rubinson, Joel. (1996). Brand loyalty: the link between attitude and behavior. Journal of Advertising Research, 36, 22-36.

Ball, Dwayne, Coelho, Pedro Simões, \& Machás, Alexandra. (2004). The role of communication and trust in explaining customer loyalty: an extension to the ECSI model. $\begin{array}{llll}\text { European Journal of } & \text { 38rketing, }\end{array}$ http://dx.doi.org/10.1108/03090560410548979

Ballantyne, Ronnie, Warren, Anne, \& Nobbs, Karinna. (2006). The evolution of brand choice. The Journal of Brand Management, 13(4-5), 4-5. http://dx.doi.org/10.1057/palgrave.bm.2540276

Baloglu, Seyhmus. (2002). Dimensions of customer loyalty: separating friends from well wishers. The Cornell Hotel and Restaurant Administration Quarterly, 43(1), 47-59. http://dx.doi.org/10.1016/S0010-8804(02)80008-8

Bandyopadhyay, Subir, \& Martell, Michael. (2007). Does attitudinal loyalty influence behavioral loyalty? A theoretical and empirical study. Journal of Retailing and Consumer Services, 14(1), 35-44. http://dx.doi.org/10.1016/j.jretconser.2006.03.00 2

Ben Sliman, S, Ferrandi, JM, Merunka, D, \& Valette-Florence, P. (2005). L'influence de la personnalité de la marque sur le comportement du consommateur: modélisation et application à de grandes enseignes d'hypermarchés en France et en Tunisie. Paper presented at the Proceedings of the 3rd Colloque de l'Association Tunisienne du Marketing, Hammamet, Tunisia, Avril.

Bennett, Rebekah. (2001). A study of brand loyalty in the business-to-business services sector.

Bennett, Rebekah, Härtel, Charmine EJ, \& McColl-Kennedy, Janet R. (2005). Experience as a moderator of involvement and satisfaction on brand loyalty in a business-to-business setting 02-314R. Industrial Marketing Management, 34(1), 97-107. http://dx.doi.org/10.1016/j.indmarman.2004.08.003

Bennett, Rebekah, \& Rundel-Thiele, Sharyn. (2005). The brand loyalty life cycle: implications for marketers. The Journal of Brand Management, 12(4), 250-263. http://dx.doi.org/10.1057/palgrave.bm.2540221 
Bennett, Rebekah, \& Rundle-Thiele, Sharyn. (2004). Customer satisfaction should not be the only goal. Journal of Services Marketing, 18(7), 514-523. http://dx.doi.org/10.1108/08876040410561848

Bloemer, Josee, De Ruyter, Ko, \& Peeters, Pascal. (1998). Investigating drivers of bank loyalty: the complex relationship between image, service quality and satisfaction. International Journal of Bank Marketing, 16(7), 276-286. http://dx.doi.org/10.1108/02652329810245984

Bowen, John T, \& Shoemaker, Stowe. (1998). Loyalty: A strategic commitment. Cornell Hotel and Restaurant Administration Quarterly, 39(1), 12-25. http://dx.doi.org/10.1177/001088049803900104

Brady, Michael K, \& Robertson, Christopher J. (2001). Searching for a consensus on the antecedent role of service quality and satisfaction: an exploratory cross-national study. Journal of Business Research, 53-60. http://dx.doi.org/10.1016/S0148-2963(99)00041-7

Brakus, J Joško, Schmitt, Bernd H, \& Zarantonello, Lia. (2009). Brand experience: what is it? How is it measured? Does it affect loyalty? Journal of Marketing, 73(3), 52-68. http://dx.doi.org/10.1509/jmkg.73.3.52

Brody, Robert P, \& Cunningham, Scott M. (1968). Personality variables and the consumer decision process. Journal of Marketing research, 50-57. http://dx.doi.org/10.2307/3149793

Caceres, Ruben Chumpitaz, \& Paparoidamis, Nicholas G. (2007). Service quality, relationship satisfaction, trust, commitment and business-to-business loyalty. European Journal of Marketing, 41(7/8), 836-867. http://dx.doi.org/10.1108/03090560710752429

Chegini, Mehrdad Goudarzvand. (2010). Customer loyalty and value key dimensions interaction in organization. China-USA Business Review, 9(8), 8-14.

Chen, Meng Zhang. (1998). A study on the relationship between brand personality, consumer satisfaction and customer loyalty. Graduate Institute of Department of Business Administration, Chang Gung University, Taoyuan.

Chinomona, Richard. (2013). The Influence Of Brand Experience On Brand Satisfaction, Trust And Attachment In South Africa. International Business \& Economics Research Journal, 12(10).

Copeland, Melvin T. (1923). Relation of consumers' buying habits to marketing methods. Harvard business review, 1(3), 282-289.

Cunningham, Ross M. (1956). Brand loyalty-what, where, how much. Harvard business review, 34(1), 116-128.

Curasi, Carolyn Folkman, \& Kennedy, Karen Norman. (2002). From prisoners to apostles: a typology of repeat buyers and loyal customers in service businesses. Journal of Services Marketing, 16(4), 322-341. http://dx.doi.org/10.1108/08876040210433220 
Day, George S. (1976). A two-dimensional concept of brand loyalty Mathematical Models in Marketing (pp. 89-89): Springer.

Dekimpe, Marnik G, Steenkamp, Jan-Benedict EM, Mellens, Martin, \& Vanden Abeele, Piet. (1997). Decline and variability in brand loyalty. International Journal of Research in Marketing, 14(5), 405-420. http://dx.doi.org/10.1016/S0167-8116(97)00020-7

Eddy, Catherine. (1999). The Correlation Between Service Quality, Satisfaction and Loyalty. Paper presented at the University of New South Wales.

Edvardsson, Bo, Johnson, Michael D, Gustafsson, Anders, \& Strandvik, Tore. (2000). The effects of satisfaction and loyalty on profits and growth: products versus services. Total Quality Management, 11(7), 917-927. http://dx.doi.org/10.1080/09544120050135461

Ekinci, Yuksel, Dawes, Philip L, \& Massey, Graham R. (2008). An extended model of the antecedents and consequences of consumer satisfaction for hospitality services. European Journal of Marketing, 42(1/2), 35-68. http://dx.doi.org/10.1108/03090560810840907

Farley, John U. (1964). Why Does" Brand Loyalty" Vary over Products? Journal of Marketing research, 9-14. http://dx.doi.org/10.2307/3150371

Fazio, Russell H, \& Zanna, Mark P. (1978). Attitudinal qualities relating to the strength of the attitude-behavior relationship. Journal of Experimental Social Psychology, 14(4), 398-408. http://dx.doi.org/10.1016/0022-1031(78)90035-5

Fishbein, Martin, \& Ajzen, Icek. (1975). Belief, attitude, intention and behavior: An introduction to theory and research.

Fournier, Susan, \& Yao, Julie L. (1997). Reviving brand loyalty: a reconceptualization within the framework of consumer-brand relationships. International Journal of Research in Marketing, 14(5), 451-472. http://dx.doi.org/10.1016/S0167-8116(97)00021-9

Foxall, Gordon R, Goldsmith, Ronald Earl, \& Brown, Stephen. (1998). Consumer psychology for marketing (Vol. 1): Cengage Learning EMEA.

Freling, Traci H, \& Forbes, Lukas P. (2005). An examination of brand personality through methodological triangulation. The Journal of Brand Management, 13(2), 148-162. http://dx.doi.org/10.1057/palgrave.bm.2540254

Giese, Joan L, \& Cote, Joseph A. (2000). Defining consumer satisfaction. Academy of marketing science review, 1(1), 1-22.

Govers, Pascalle CM, \& Schoormans, Jan PL. (2005). Product personality and its influence on consumer preference. Journal of Consumer Marketing, 22(4), 189-197. http://dx.doi.org/10.1108/07363760510605308

Guest, Lester. (1944). A study of brand loyalty. Journal of Applied Psychology, 28(1), 16. http://dx.doi.org/10.1037/h0053554

Guo, Li-Jing. (2003). The Effects of Personality Trait and Brand Personality on Brand 
Preference. Graduate Institute of Management Science, National Chiao Tung University, Hsinchu.

Haghkhah, Azam, Hamid, Abdul, Ben, Abu Bakar, Ebrahimpour, Alireza, Roghanian, Parastoo, \& Gheysari, Hamed. (2013). Commitment and Customer Loyalty in Business-To-Business Context. European Journal of Business \& Management, 5(19).

Hallowell, Roger. (1996). The relationships of customer satisfaction, customer loyalty, and profitability: an empirical study. International journal of service industry Management, 7(4), 27-42. http://dx.doi.org/10.1108/09564239610129931

He, Hongwei, Li, Yan, \& Harris, Lloyd. (2012). Social identity perspective on brand loyalty. Journal of Business Research, 65(5), 648-657. http://dx.doi.org/10.1016/j.jbusres.2011.03.007

Helgeson, James G, \& Supphellen, Magne. (2004). A conceptual and measurement comparison of self-congruity and brand personality-The impact of socially desirable responding. International Journal of Market Research, 46(2), 205-233.

Howell, D. (2004). Today's consumers more open to try new brands. DSN Retailing Today: October.

Jacoby, Jacob. (1971). A model of multi-brand loyalty. Journal of Advertising Research, 11(3), 25-31.

Jacoby, Jacob, \& Chestnut, Robert W. (1978). Brand loyalty: Measurement and management. Wiley New York.

Jones, Michael A, \& Suh, Jaebeom. (2000). Transaction-specific satisfaction and overall satisfaction: an empirical analysis. Journal of Services Marketing, 14(2), 147-159. http://dx.doi.org/10.1108/08876040010371555

Jones, Thomas O, \& Sasser, W Earl. (1995). Why satisfied customers defect. Harvard business review, 73(6), 88-\&.

Kandampully, Jay, \& Suhartanto, Dwi. (2000). Customer loyalty in the hotel industry: the role of customer satisfaction and image. International journal of contemporary hospitality management, 12(6), 346-351. http://dx.doi.org/10.1108/09596110010342559

Kapferer, Jean-Noël. (2005). The roots of brand loyalty decline: An international comparison. Ivey Business Journal, 69(4), 1-6.

Kaur, Harsandaldeep, \& Soch, Harmeen. (2013). Mediating roles of commitment and corporate image in the formation of customer loyalty. Journal of Indian Business Research, 5(1), 33-51. http://dx.doi.org/10.1108/17554191311303376

Kotler, Philip, \& Keller, Kevin Lane. (2005). Marketing Management (Marketing Management): Upper Saddle River: Prentice Hall.

Kraus, Stephen J. (1995). Attitudes and the prediction of behavior: A meta-analysis of the 
empirical literature. Personality and Social Psychology Bulletin, 21(1), 58-75. http://dx.doi.org/10.1177/0146167295211007

Lam, Shun Yin, Shankar, Venkatesh, Erramilli, M Krishna, \& Murthy, Bvsan. (2004). Customer value, satisfaction, loyalty, and switching costs: an illustration from a business-to-business service context. Journal of the academy of marketing science, 32(3), 293-311. http://dx.doi.org/10.1177/0092070304263330

Levy, Sydney J. (1999). Symbols for sale. reprinted in: Brands, Consumers, Symbols \& Research, 203-212.

Lewis, Barbara R, \& Soureli, Magdalini. (2006). The antecedents of consumer loyalty in retail banking. Journal of Consumer Behaviour, 5(1), 15-31. http://dx.doi.org/10.1002/cb.46

Liang, Chiung-Ju, \& Wang, Wen-Hung. (2004). Attributes, benefits, customer satisfaction and behavioral loyalty-an integrative research of financial services industry in Taiwan. Journal of Services Research, 4(1), 57-91.

Liang, Chiung-Ju, \& Wang, Wen-Hung. (2007). The behavioral sequence of information education services industry in Taiwan: relationship bonding tactics, relationship quality and behavioral loyalty. Measuring Business Excellence, 11(2), 62-74. http://dx.doi.org/10.1108/13683040710752742

Lin, Hsin-Hui, \& Wang, Yi-Shun. (2006). An examination of the determinants of customer loyalty in mobile commerce contexts. Information \& Management, 43(3), 271-282. http://dx.doi.org/10.1016/j.im.2005.08.001

Lin, Long-Yi. (2010). The relationship of consumer personality trait, brand personality and brand loyalty: an empirical study of toys and video games buyers. Journal of Product \& Brand Management, 19(1), 4-17. http://dx.doi.org/10.1108/10610421011018347

Liu, Annie H. (2006). Customer value and switching costs in business services: developing exit barriers through strategic value management. Journal of Business \& Industrial Marketing, 21(1), 30-37. http://dx.doi.org/10.1108/08858620610643157

Lombart, Cindy, \& Louis, Didier. (2012). Consumer satisfaction and loyalty: Two main consequences of retailer personality. Journal of Retailing and Consumer Services, 19(6), 644-652. http://dx.doi.org/10.1016/j.jretconser.2012.08.007

Louis, Didier, \& Lombart, Cindy. (2010). Impact of brand personality on three major relational consequences (trust, attachment, and commitment to the brand). Journal of Product \& Brand Management, 19(2), 114-130. http://dx.doi.org/10.1108/10610421011033467

Loveman, Gary W. (1998). Employee satisfaction, customer loyalty, and financial performance an empirical examination of the service profit chain in retail banking. Journal of Service Research, 1(1), 18-31. http://dx.doi.org/10.1177/109467059800100103

Magin, Stephanie, Algesheimer, René, Huber, Frank, \& Herrmann, Andreas. (2003). The impact of brand personality and customer satisfaction on customer's loyalty: theoretical 
approach and findings of a causal analytical study in the sector of internet service providers. Electronic Markets, 13(4), 294-308. http://dx.doi.org/10.1080/1019678032000135572

Matzler, Kurt, Füller, Johann, Renzl, Birgit, Herting, Stephan, \& Späth, Sebastian. (2008). Customer satisfaction with Alpine ski areas: the moderating effects of personal, situational, and product factors. Journal of Travel Research, 46(4), 403-413. http://dx.doi.org/10.1177/0047287507312401

Mellens, Martin, Dekimpe, Marnik, \& Steenkamp, J. (1995). A review of brand-loyalty measures in marketing. DTEW Research Report 9516, 1-27.

Mengxia, Zhang. (2007). Impact of brand personality on PALI: a comparative research between two different brands. International Management Review, 3(3), 36-46.

Merrilees, Bill, \& Miller, Dale. (2001). Antecedents of brand-personality in Australian retailing: an exploratory study. Paper presented at the ANZMAC 2001.

Nadeem, Mohammed M. (2007). Post-Purchase Dissonance: The Wisdom of the'Repeat'Purchases. Journal of Global Business Issues, 1(2).

O'brien, Terrence. (1971). Stages of consumer decision making. Journal of Marketing research, 283-289. http://dx.doi.org/10.2307/3149564

Ojo, Olu. (2010). The relationship between service quality and customer satisfaction in the telecommunication industry: Evidence from Nigeria. BRAND. Broad Research in Accounting, Negotiation, and Distribution, 1(1), 88-100.

Oliva, Terence A, Oliver, Richard L, \& MacMillan, Ian C. (1992). A catastrophe model for developing service satisfaction strategies. The Journal of Marketing, 83-95. http://dx.doi.org/10.2307/1252298

Ouwersloot, Hans, \& Tudorica, Anamaria. (2001). Brand personality creation through advertising: Maastricht Accounting and Auditing Research and Education Center (MARC).

Patterson, Paul G, \& Spreng, Richard A. (1997). Modelling the relationship between perceived value, satisfaction and repurchase intentions in a business-to-business, services context: an empirical examination. International journal of service industry Management, 8(5), 414-434. http://dx.doi.org/10.1108/09564239710189835

Plummer, Joseph T. (2000). How personality makes a difference. Journal of Advertising Research, 40(06), 79-84.

Rezaei, Sajad. (2015). Segmenting consumer decision-making styles (CDMS) toward marketing practice: A partial least squares (PLS) path modeling approach. Journal of Retailing and Consumer Services, 22, 1-15. http://dx.doi.org/10.1016/j.jretconser.2014.09.001

Rezaei, Sajad, \& Amin, Muslim. (2013). Exploring online repurchase behavioural intention of university students in Malaysia. Journal for Global Business Advancement, 6(2), 92-119. http://dx.doi.org/10.1504/JGBA.2013.053561 
Ringham, LA, Johnson, LW, \& Morton, CP. (1994). Customer satisfaction and loyalty for a continuous consumer service. Australasian Journal of Market Research, 2(2), 43-48.

Roustasekehravani, Alireza, \& Hamid, Abu Bakar Abdul. (2014). Do Brand Personality Really Enhance Satisfaction and Loyalty Toward Brand? A Review of Theory and Empirical Research. European Journal of Business and Management, 6(25), 174-183.

Rundle-Thiele, Sharyn. (2005). Elaborating customer loyalty: exploring loyalty to wine retailers. Journal of Retailing and Consumer Services, 12(5), 333-344. http://dx.doi.org/10.1016/j.jretconser.2004.11.002

Rundle-Thiele, Sharyn, \& Bennett, Rebekah. (2001). A brand for all seasons? A discussion of brand loyalty approaches and their applicability for different markets. Journal of Product \& Brand Management, 10(1), 25-37. http://dx.doi.org/10.1108/10610420110382803

Schriver, Steve. (1997). Customer loyalty: Going, going. American Demographics, 19(9), 20.

Sheth, Jagdish N, \& Venkatesan, M. (1968). Risk-reduction processes in repetitive consumer behavior. Journal of Marketing research, 307-310. http://dx.doi.org/10.2307/3150350

Stauss, Bernd, \& Neuhaus, Patricia. (1997). The qualitative satisfaction model. International journal of service industry Management, 8(3), 236-249. http://dx.doi.org/10.1108/09564239710185424

Tepeci, Mustafa. (1999). Increasing brand loyalty in the hospitality industry. International journal of contemporary hospitality management, 11(5), 223-230. http://dx.doi.org/10.1108/09596119910272757

Yi, YJ, \& La, SN. (2002). Brand personality-brand identification-brand equity model: an exploratory study on the difference between users vs. non-users. Korean Marketing Review, 17(3), 1-34.

Zentes, Joachim, Morschett, Dirk, \& Schramm-Klein, Hanna. (2008). Brand personality of retailers-an analysis of its applicability and its effect on store loyalty. The International Review of Retail, Distribution and Consumer Research, 18(2), 167-184. http://dx.doi.org/10.1080/09593960701868282

Zins, Andreas H. (2001). Relative attitudes and commitment in customer loyalty models: some experiences in the commercial airline industry. International journal of service industry Management, 12(3), 269-294. http://dx.doi.org/10.1108/EUM0000000005521

\section{Copyright Disclaimer}

Copyright for this article is retained by the author(s), with first publication rights granted to the journal.

This is an open-access article distributed under the terms and conditions of the Creative Commons Attribution license (http://creativecommons.org/licenses/by/3.0/). 